Original Research Paper

\title{
Preventive Effect of Marsileacrenata Leaves and Stalks Juices Against Urolithiasis Showed by Improving of Kidney Function
}

\author{
Sri Murwani \\ School of Veterinary Medicine, Brawijaya University, Jl Veteran 65145, Malang, Indonesia
}

Article history

Received: 04-12-2015

Revised: 13-01-2016

Accepted: 02-02-2016

Email:muratinia@ub.ac.id

\begin{abstract}
Nowadays urolithiasisis still as a major problem in pet animals, particularly for dogs and cats. Urolithiasisis caused by formation of crystals in the urinary tract that inhibit the process of urination. It is frequently as an impact of dry food given regularly, keeping animals in a place so that the movement of the animal becomes restricted, lack of water intake, or by microbial infection. Marsileacrenata contains potassium, flavonoid, alkaloid and polyphenol. All these compounds can act as diuretic, antioxidant and anti-inflammatory, which may favourably prevent urolithiasis. Accordingly in this study, oral administration of the M. crenata leaves extract and stalks juice to rats as animal models dealing with prevention disturbance kidney function in urolithiasis were investigated. Post-test only control group of true experimental design and complete random design were applied in this research. Wistar male rats ( $R$. novergicus) of 12-week-old were used in the present study. These animal models were divided into six groups; negative control, positive control (treated with $0.75 \%$ ethylene glycol/EG and $2 \%$ ammonium chloride/AC, as much as $2 \mathrm{~mL} \mathrm{day}^{-1}$ for 10 days) and four groups of preventive control (treated similarly as positive control and oral administration of 5, 10, 20 and $40 \%$ M. crenata leaves and stalks juices with dose of $1 \mathrm{~mL} 100 \mathrm{~g} \mathrm{~g}^{-1} \mathrm{BW}$ for 10 days. Several parameters correlated with urolithiasis including Blood Urea Nitrogen (BUN) and serum creatinine, urine craetinine and creatinine clearance $\left(\mathrm{C}_{\mathrm{cr}}\right)$ was studied. The data obtained were analysed by one-way ANOVA, $\alpha=0.05$. Such results revealed that $M$. crenata leaves extract and stalks juice prevent kidney function disturbance in urolithiasisrats, which are indicated by decrease of BUN and increase of $\mathrm{C}_{\mathrm{cr}}$.
\end{abstract}

Keywords: Preventive, Kidney Function, Urolithiasis, Marsileacrenata

\section{Introduction}

Urolithiasis is a pet animal's common disease particularly occurs in dogs and cats due to the formation of crystal aggregation and urine minerals sediment in the urinary tract. The stones form in the urinary bladder in varying size and numbers secondary to infection, dietary influences and genetics. Urolithiasis may be associated with various degrees of renal insufficiency. Stones can form in any part of the urinary tract of dogs and cats and can contribute to lower urinary tract disease, pyelonephritis, idiopathic cystitis and chronic renal failure. Types of stones include struvite, calcium oxalate, urat, cystine, calcium phosphate and silicate (Buffington, 2001; Kang et al., 2014; Westropp, 2015; Miller et al., 2010).

Base on medical record 2008 in Jakarta Animal Hospital, Institute of Agriculture Bogor and Veterinary Clinic PDHB drh. CucuKartini, case of urolithiasis increased from 2007. The cases frequently in male, with kind of stones are $42 \%$ calcium oxalate, $33 \%$ struvite, $17 \%$ silica and 8\% cystine (Mariyani, 2009). The Ohio State University Veterinary Hospital evaluates 109 cats with stranguria and 15 cats of them are urolithiasis (Buffington, 2001). Waltham Centre for Pet Nutrition reported that the newest case of feline lower urinary tract disease is $0.5-1 \%$ per year from cat population in Europe and South America.

The most common crystal in dogs and cats urolithiasis is calcium oxalate $\left(\mathrm{CaC}_{2} \mathrm{O}_{4}\right)$ and struvite (magnesium ammonium phosphate). Generally, treatment of urolithiasis was performed by drug administration either orally or using catheter. However, after treatment the urolithiasis can occur repeatedly (Buffington, 2001; Miller et al., 2010). Sparkes and Philippe (2008) reported that without preventive actions, approximately $20-50 \%$ of urolithiasis in cat and dog are relapse.

Blood Urea Nitrogen (BUN) is a normal waste product in the blood that comes from the breakdown of protein metabolism and carried to the kidneys for 
excretion. It is normally removed from the blood by the kidneys, provides a rough measurement of the glomerular filtration rate, the rate at which blood is filtered in the kidneys. Nearly all kidney diseases cause inadequate excretion of urea, elevating BUN levels in the blood. Increased BUN levels suggest impaired kidney function (Miller et al., 2010; NKF, 2015).

Creatinine is a waste product in your blood, end product breakdown of creatine, an important component of muscle. The production of creatinine depends on muscle mass, which varies very little. Exclusively the kidneys excrete creatinine and its level in the blood is proportional to the glomerular filtration rate. The serum creatinine level (serum is the clear liquid that remains after whole blood has clotted) provides a more sensitive test of kidney function than BUN because kidney impairment is almost the only cause of elevated creatinine. It can also be measured with a urine test (Miller et al., 2010; NKF, 2015).

Little or no tubular re absorption of creatinine occurs. If the filtration in the kidney is deficient, creatinine blood levels rise. Therefore, creatinine levels in blood and urine may be used to calculate the creatinine clearance $\left(\mathrm{CrCl} / \mathrm{C}_{\mathrm{cr}}\right)$, which correlates with the Glomerular Filtration Rate (GFR). Bloodcreatinine levels may also be used alone to calculate the estimated GFR (eGFR). The GFR is clinically important because it is a measurement of renal function. If the GFR falls, can be predicted it is a kidney disease (Miller et al., 2010; Lerma, 2015).

Nowadays, there is has been growing a research on prospecting of natural products as new drugs. Some traditional herbs, such as kumis kucing (Orthosiphonaristatus), blue grapes fruit (Vitisvinifera L.) and tempuyung leaves (Sonchusarvensis), contain valuable substances, playing important roles as preventive agent against infection or disease. Water semanggi $(M$. crenata), one of wild plant, contains active chemical substances such as potassium ion $\left(\mathrm{K}^{+}\right)$, flavonoid, alkaloid and polyphenol. Its potassium ion and flavonoid possess diuretics functional, as antioxidant and anti-inflammation, whereas its alkaloid and polyphenol has antioxidant activity (Afriastini, 2003). Moreover, M. creanata is believed contains active chemical substances able to destroy crystals or to prevent urolithiasis.

Therefore, in this experiment, the effects of $M$. crenata leaves and stalks juice toward prevention of kidney tissue damage in Wistar male rats urolithiasis by mean of oral administration were investigated. As positive control, the animal models were induced by mixture of $0.75 \%$ EG and $2 \%$ AC. Jagannath et al. (2012) reported that administration of these chemical combinations for ten days could induce formation of calcium oxalate crystals in the urinary tract. Various concentrations of $M$. crenataextract were administrated orally to the urolithiasis rats. Some parameters, such as $\mathrm{BUN}, \mathrm{C}_{\mathrm{cr}}$ and kidney tissue damage, were then observed conceiving the ability of water semanggi (M. crenata) to prevent decreasing of kidney function in urolithiasis Wistar male rats ( $R$. norvegicus).
Table 1. Groups of animal treatment

\begin{tabular}{ll}
\hline Group & Treatment \\
\hline Negative control & Normal condition and normal diet \\
Positive control & Normal diet $+0,75 \%$ EG $+2 \%$ AC \\
Treatment 1 & Normal diet $+5 \%$ juice $M$. crenata \\
& $+0,75 \%$ EG $+2 \%$ AC \\
Treatment 2 & Normal diet $+10 \%$ juice $M$. crenata \\
& $+0,75 \%$ EG $+2 \%$ AC \\
Treatment 3 & Normal diet $+20 \%$ juice $M$. crenata \\
& $+0,75 \%$ EG $+2 \%$ AC \\
Treatment 4 & Normal diet $+40 \%$ juice M. crenata \\
& $+0,75 \%$ EG $+2 \%$ AC \\
\hline
\end{tabular}

\section{Methods}

\section{Animal Model and Treatment}

Inclusion criteria of the samples are health Wistarmale rats with the body weight of 175-200 grams and 12 weeks old, whereas exclusion criteria is the animal model dead in the progress of investigation. Wistarmale rats as the animal models were obtained from the Animal Experimental Development Unit of GadjahMada University and had certificated by The Ethical Committee Medical Research of Medical Faculty, Brawijaya University (No. 421/EC/KEPK/07/2013). Number of samples wasp (n-1) $\geq 15$. The animals were divided into negative control, positive control and treatment groups as shown in Table 1. The animals were placed in metabolic cage and were adapted for 7 days before treatment.

\section{Procedures}

\section{Inducing Urolithiasis}

Combination of $0.75 \%$ Ethylene Glycol (EG) and 2\% Ammonium Chloride (AC) as much as $2 \mathrm{~mL}$ day $^{-1}$ was used to induce urolithiasis. This substance was given for 10subsequent days (modified Anggraini, 2013).

\section{Administration of Juice Leaves and Stalks M. crenata}

The herb was obtained from UPT MatrikaMedikaBatu, East Java, Indonesia. The juice was prepared using a commercially available fruit juicer and its concentration was considered as $100 \%$. Thereafter, the resulted juice was diluted with water to provide dose of $5,10,20$ and $40 \%(\mathrm{v} / \mathrm{v})$. Each dose of juice was treated orally using stomach sonde to the animal models $1 \mathrm{~mL} 100 \mathrm{~g}^{-1} \mathrm{BW}$ for 10 days (Purwono, 2009).

\section{Measurement of BUN, Serum Creatinine and Urine Creatinine}

All measurement of BUN, serum creatinine, and urinecratinine were conducted at Installation of Central Laboratory, Dr. Saiful Anwar Hospital, Malang and East Java, Indonesia using Beckman Coulter AU Analyser (OSR6178). 


\section{Calculation of Creatinine Clearance $\left(C_{c r}\right)$}

Creatinine clearance was calculated according to the following equation:

$$
\operatorname{Ccr}(\mu l / \mathrm{min})=\frac{\begin{array}{l}
\text { Urine creatinine concentration }(\mathrm{mg} / \mathrm{dL}) \\
\times 24 \text { hurine volume }(\mu l)
\end{array}}{\text { Serum creatinine } \times 24 \times 60 \mathrm{~min}}
$$

\section{Data Analysis}

The data was analysed statistically using one-way ANOVA, with $\alpha=0.05$.

\section{Results}

\section{Blood Urea Nitrogen (BUN)}

Blood Urea Nitrogen increased significantly in urolithiasis rats (induced by combination of $0.75 \% \mathrm{EG}$ and $2 \% \mathrm{AC}$ ). BUN of treated animals insignificantly decreased in dose 5 and $10 \%$, but significantly with in dose 20 and $40 \%$ of $M$. crenata as shown in Table 2 .

\section{Serum Creatinine and Urine Creatinine}

Serum creatinine in urolithiasis group increased significantly to negative control and reduced after administration 20 and $40 \%$ juice of leaves and stalks $M$. crenata accompanied by increasing of urine creatinine (Table 3 ).

\section{Creatinine Clearance $\left(C_{c r}\right)$}

Urolithiasis induced by combination $0.75 \%$ EG and $2 \%$ AC caused decreasing of Ccr. The Ccr increased afterjuice of leaves and stalks of M. crenata was given (Table 4).

\section{Histopathology}

Combination of $0.75 \%$ EG and $2 \%$ AC induced urolithiasis. Tissue damages in the glomeruli, Bowman

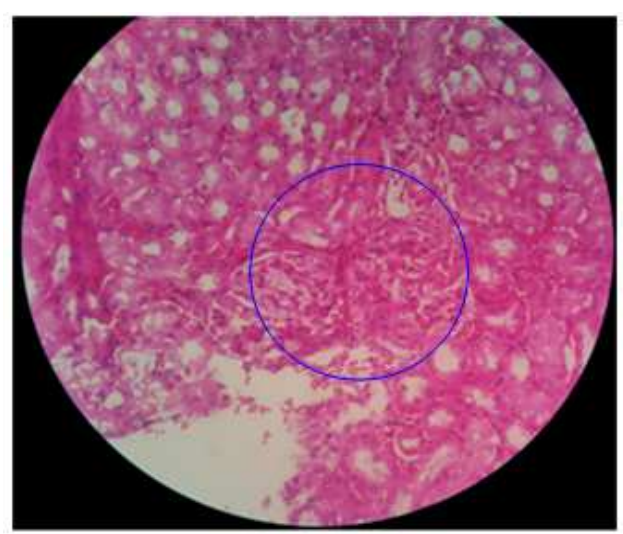

(a) capsule, arteriole glomerular, proximal convoluted tubule, and distal convoluted tubule of the kidney were occurred. Its indicated by inflammation response and necrosis process (Fig. 1). This condition was significantly different with the negative control (normal rat) where tissue in the kidney was still in normal condition as shown in Fig. 2. From this work, it was found that treatment of rats with M. crenata $5 \%$ (Fig. 3 ) and $10 \%$ (Fig. 4) did not show significant improvement of tissue damages. However, at higher concentration of the juice results in lower tissue damages shown in Fig. 5 and 6 for treatment with 20 and $40 \%$ M. crenata, respectively.

Table 2. Result of Tukey analysis $(\alpha=0.05)$ of rats BUN level

\begin{tabular}{ll}
\hline Group & Mean \pm SD BUN (mg/dL) \\
\hline Negative control & $14.90 \pm 0.02^{\mathrm{a}}$ \\
Positive control & $19.65 \pm 0.08^{\mathrm{d}}$ \\
$5 \%$ of $M$. crenata & $19.63 \pm 0.05^{\mathrm{d}}$ \\
$10 \%$ of $M$. crenata & $19.63 \pm 0.04^{\mathrm{d}}$ \\
$20 \%$ of $M$. crenata & $16.24 \pm 0.04^{\mathrm{c}}$ \\
$40 \%$ of $M$. crenata & $15.00 \pm 0.02^{\mathrm{b}}$ \\
\hline
\end{tabular}

Table 3. Result of Tukey analysis $(\alpha=0.05)$ of rats serum creatinine and urine creatinine levels

\begin{tabular}{lll}
\hline Group & $\begin{array}{l}\text { Mean } \pm \text { SD Serum } \\
\text { Creatinine }(\mu \mathrm{g} / \mathrm{mL})\end{array}$ & $\begin{array}{l}\text { Mean } \pm \text { SD Urine } \\
\text { Creatinine }(\mu \mathrm{g} / \mathrm{mL})\end{array}$ \\
\hline Negative control & $0.42 \pm 0.02^{\mathrm{a}}$ & $91.55 \pm 0.12^{\mathrm{f}}$ \\
Positive control & $0.66 \pm 0.01^{\mathrm{c}}$ & $56.98 \pm 0.09^{\mathrm{a}}$ \\
$5 \%$ of $M$. crenata & $0.68 \pm 0.01^{\mathrm{bc}}$ & $67.34 \pm 0.09^{\mathrm{b}}$ \\
$10 \%$ of $M$. crenata & $0.64 \pm 0.01^{\mathrm{c}}$ & $68.22 \pm 0.18^{\mathrm{c}}$ \\
$20 \%$ of $M$. crenata & $0.48 \pm 0.01^{\mathrm{b}}$ & $80.56 \pm 0.07^{\mathrm{d}}$ \\
$40 \%$ of $M$. crenata & $0.47 \pm 0.01^{\mathrm{b}}$ & $82.78 \pm 0.10^{\mathrm{e}}$ \\
\hline
\end{tabular}

Table 4. Result of Tukey analysis $(\alpha=0.05)$ of creatinine clearance

\begin{tabular}{lll}
\hline & $\begin{array}{l}\text { Mean } \pm \text { SD 24 h } \\
\text { Urine Volume }(\mu \mathrm{L})\end{array}$ & $\begin{array}{l}\text { Mean } \pm \text { SD } \\
\mathrm{C}_{\mathrm{Cr}}(\mu \mathrm{L} / \mathrm{min})\end{array}$ \\
\hline Negative control & $6619 \pm 27.34^{\mathrm{d}}$ & $1003.073 \pm 36.659^{\mathrm{e}}$ \\
Positive control & $5000 \pm 46.01^{\mathrm{a}}$ & $314.885 \pm 36.088^{\mathrm{a}}$ \\
$5 \%$ of $M$. crenata & $6200 \pm 07.07^{\mathrm{c}}$ & $426.440 \pm 6.554^{\mathrm{b}}$ \\
$10 \%$ of $M$. crenata & $6200 \pm 14.14^{\mathrm{c}}$ & $459.011 \pm 6.911^{\mathrm{b}}$ \\
$20 \%$ of $M$. crenata & $6000 \pm 39.16^{\mathrm{b}}$ & $698.907 \pm 9.904^{\mathrm{c}}$ \\
$40 \%$ of $M$. crenata & $6900 \pm 70.71^{\mathrm{e}}$ & $844.196 \pm 18.081^{\mathrm{d}}$ \\
\hline
\end{tabular}

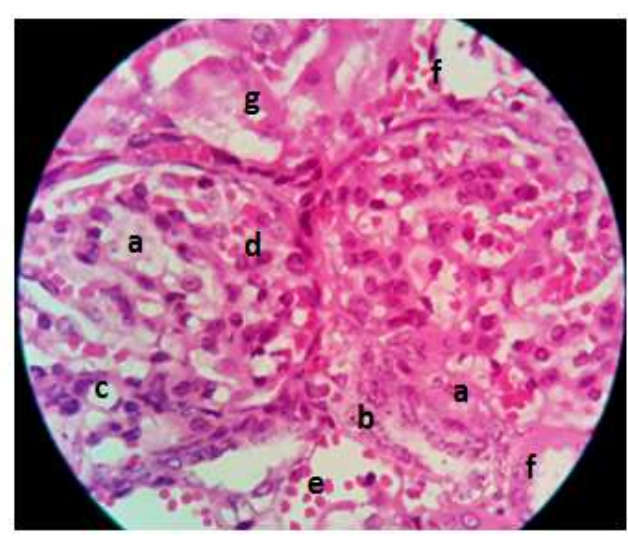

(b)

Fig. 1. Histopathology kidney of urolithiasis mice. It is showed tissue damage in: (a) glomeruli; (b) Bowman capsule; (c) inflammation cells; (d) necrosis; (e) arteriole glomerular; (f) proximal convoluted tubule; (g) distal convoluted tubule (A. 400 magnification; B. 1000 magnification of blue cycle) 


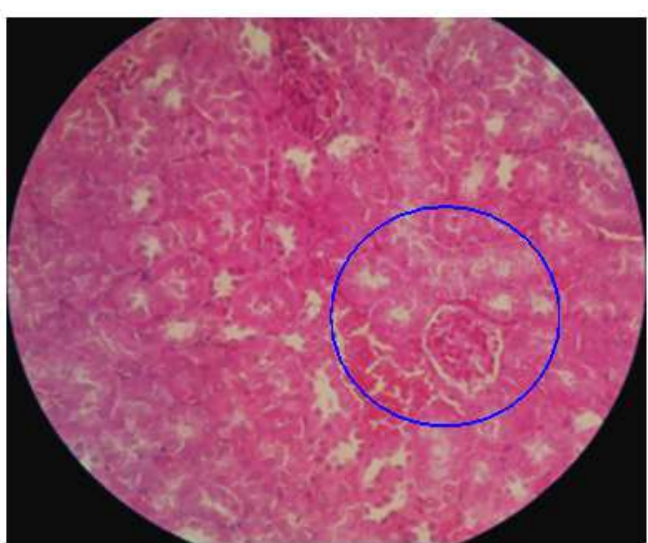

(a)

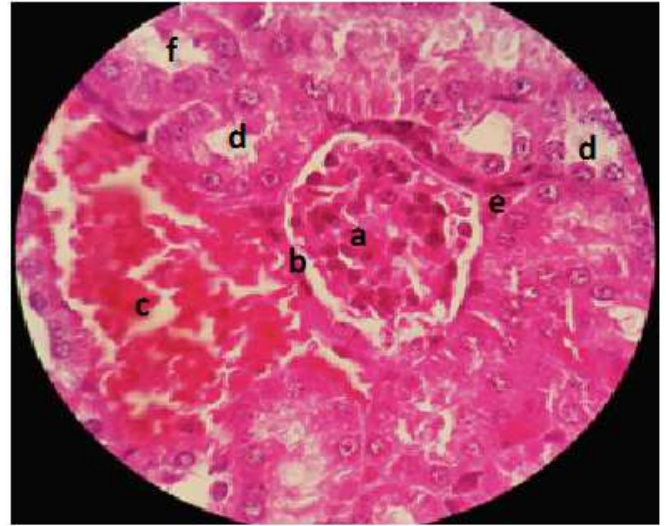

(b)

Fig. 2. Normal kidney. Normal histology: (a) glomerulus; (b) Bowman capsule; (c) vena intratubules; (d) proximal convoluted tubule; (e) arteriole glomerular; (f) distal convoluted tubule (A. 400 magnification; B. 1000 magnification of blue cycle)

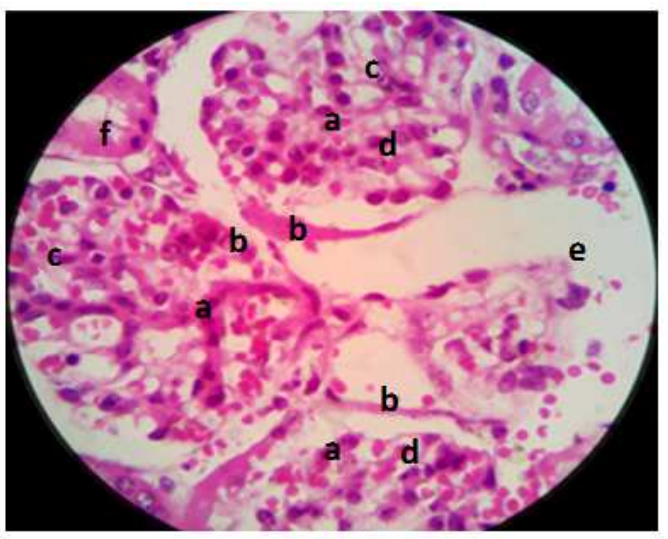

(a)

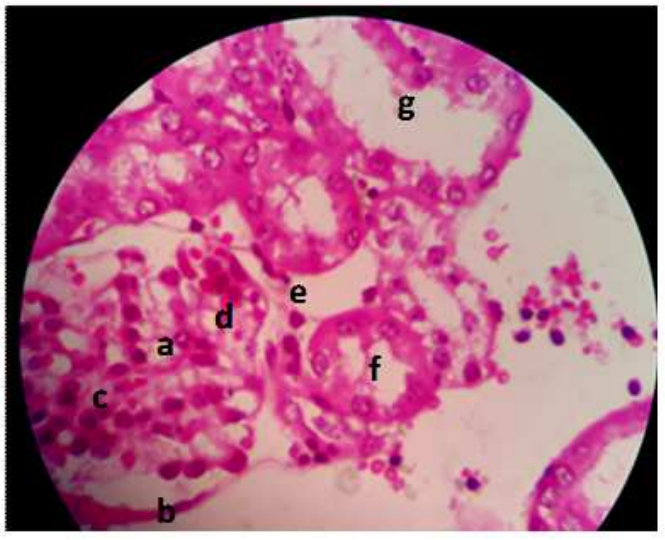

(b)

Fig. 3. Kidney histopathology of the treatment group 1 (5\% juice $M$. crenatabefore becoming induced urolithiasis) It is showed tissue damages in: (a) glomeruli; (b) Bowman capsule; (c) inflammation cells; (d) necrosis; (e) arteriole glomerular; (f) proximal convoluted tubule; (g) distal convoluted tubule (A and B 1000 magnification)

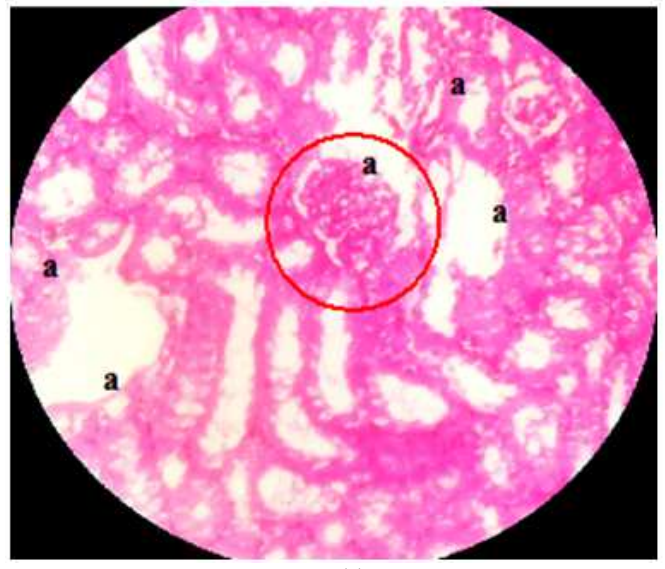

(a)

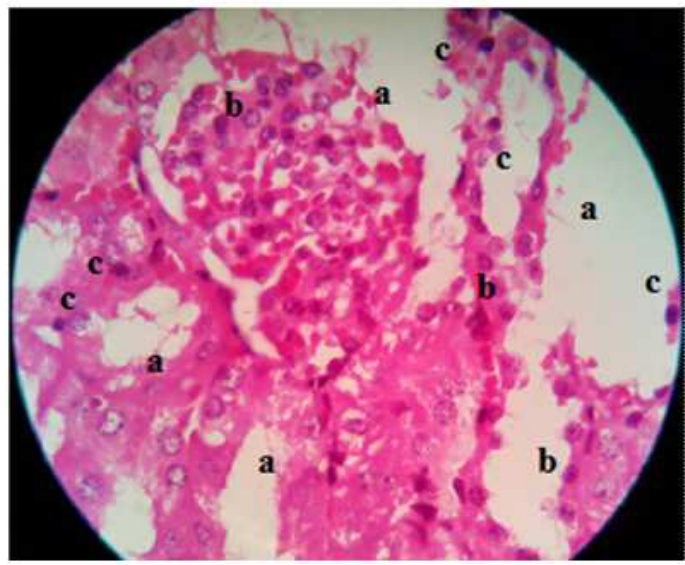

(b)

Fig. 4. Kidney histopathology of the treatment group 2 (10\% juice M. crenata before becoming induced urolithiasis). Still found any tissue damagesin the glomerulus, Bowman capsules, proximal and distal convoluted tubules were signed by: (a) cell and nucleus cell lysis; (b) necrosis; (c) inflammation cells. (A. 400 magnification, B. 1000 magnification of red cycle) 


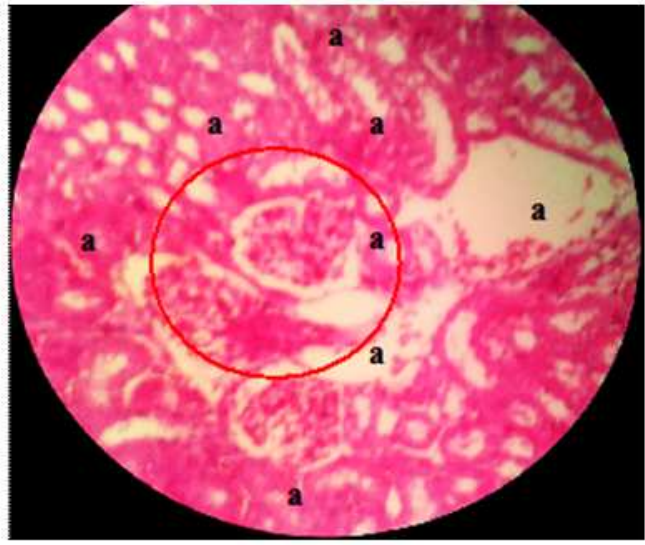

(a)

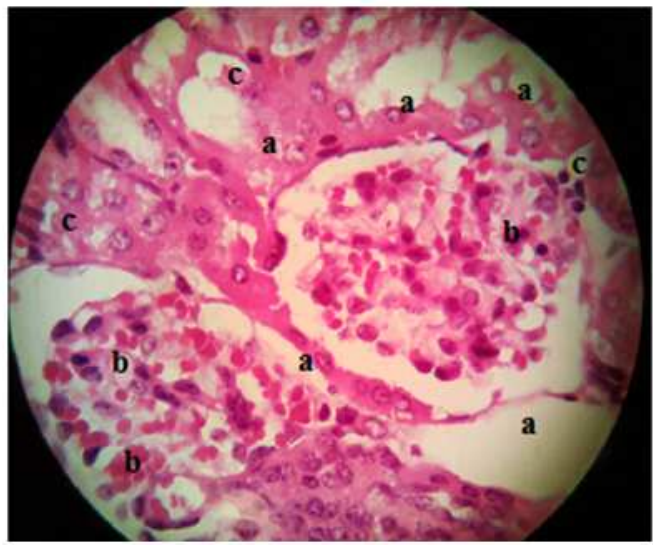

(b)

Fig. 5. Kidney histopathology of the treatment group 3 (20\% juice M. crenatabefore becoming induced urolithiasis).A decline of kidney tissue damages, it was indicated by decreasing of: (a) cell and nucleus cell lysis; (b) necrosis; (c) inflammation cells in the glomerulus, Bowman capsules, proximal and distal convoluted tubules (A. 400 magnification, B. 1000 magnification of red cycle)

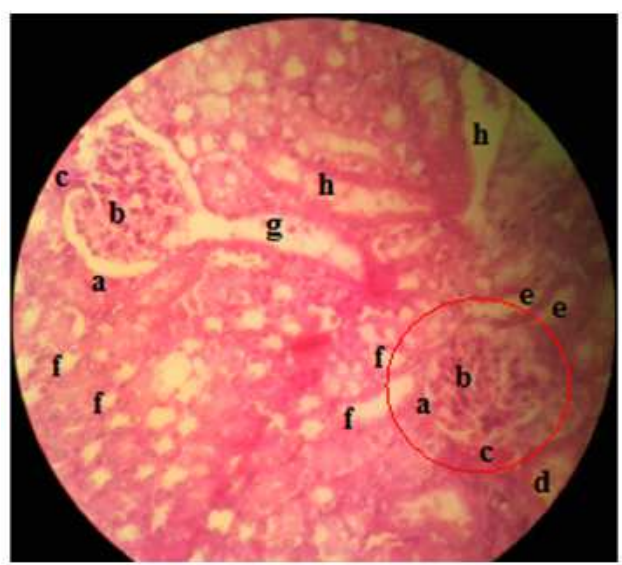

(a)

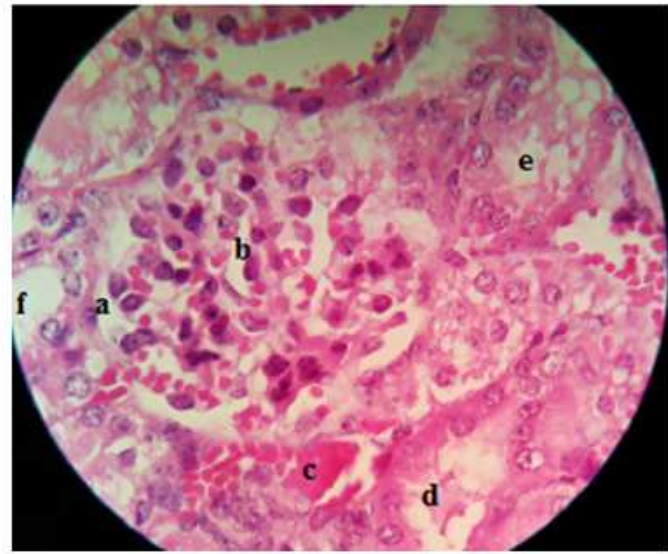

(b)

Fig. 6. Kidney histopathology of the treatment group 4 (40\% juice $M$. crenata before becoming induced urolithiasis). The juicelowerskidney tissuedamage andnormaltissueapproaching. There are some normal histology of: (a) Bowman capsules, (b) glomerulus, (c) arteriole glomerular, (d) vena intratubules, (e) proximal convoluted tubules, (f) distal convoluted tubules, (g) junction of glomerulus capsule and proximal tubule, (h) koligens duct (A. 400 magnification, B. 1000 magnification of red cycle)

\section{Discussion}

\section{Blood Urea Nitrogen (BUN)}

Normal rat BUN both male and female is in range 15-16 mg dL (Baker et al., 1979). BUN is an indication of renal (kidney) health (Miller et al., 2010). This research, BUN increased significantly in urolithiasis rats induced by combination of $0.75 \% \mathrm{EG}$ and $2 \% \mathrm{AC}$. Increasing the BUN levels suggest impaired kidney function. This may be due to acute or chronic disease, damage, or failure the kidney. Juice of leaves and stalks of $M$. crenata can destruct urine $\mathrm{CaC}_{2} \mathrm{O}_{4}$ crystals, which is indicated by significantly decrease of urine sediment (Murwani et al., 2015). Tissue damages may caused by toxic effect of EG and AC, inflammation process, free radicals and traumatic effect of urolithiasis.

The presence of potassium ion $\left(\mathrm{K}^{+}\right)$and flavonoid in leaves and stalks of $M$. crenata may responsible for crystals destruction. Crystal fragments leave the body with urine as the following reaction (Yilmaz et al., 2011):

$$
2 \mathrm{~K}^{+}+\mathrm{CaC}_{2} \mathrm{O}_{4} \rightarrow \mathrm{K}_{2} \mathrm{C}_{2} \mathrm{O}_{4}+\mathrm{Ca}^{2+}
$$

$\mathrm{K}_{2} \mathrm{C}_{2} \mathrm{O}_{4}$ or potassium oxalate stone is water-soluble. $\mathrm{K}^{+}$ions inhibit interaction of Caions with carbonate, oxalate or uric acid, so that calcium exists in the form of soluble ions (Hidayati et al., 2009). 
$\mathrm{CaC}_{2} \mathrm{O}_{4}$ crystal may interact with $-\mathrm{OH}$ groups of flavonoid to form Ca-flavonoid complex. This complex is more water-soluble and easily emerges from the bodyduring urination. Furthermore, flavonoid also plays as diuretic substance (Suharjo and Cahyono, 2009).

$\mathrm{K}^{+}$and $\mathrm{Na}^{+}$ions maintain balance of kidney electrolytes. Factors influencing acid secretion are alteration of $\mathrm{K}^{+}$ions concentration, $\mathrm{CO}_{2}$ intracellular pressure, level of anhydrase carbonate and some hormones such as aldosterone, steroid adrenocortex, angiotensin II (Ganong, 2003).

\section{Serum Creatinine and Urine Creatinine}

Combination of $0.75 \%$ EG and $2 \%$ AC induced urolithiasis and causing kidney tissue damage, such as inflammation, oedema, necrosis, hydropicdegeneration and lipid degeneration (Murwani et al., 2015). The poor function of kidney caused increasing of serum creatinine and decreasing urine creatinine. It is indicated strong kidney tissue damages (Miller et al., 2010; NKF, 2015). Probably, it is caused by alternation of reabsorption function of the kidney at proximal convoluted tubules, henle loop, distal convoluted tubules, or collectivus tubules.

Serum creatinine (a blood measurement) is an important indicator of renal health because it is an easily measured by product of muscle metabolism that is excreted unchanged by the kidneys. Creatinine is removed from the blood chiefly by the kidneys, primarily by glomerular filtration, but also by proximal tubular secretion. Little or no tubular reabsorption of creatinine occurs. If the filtration in the kidney is deficient, creatinine blood levels rise (Miller et al., 2010; NKF, 2015).

In health rat,the serum creatinine is $0.50 \pm 0.07 \mathrm{mg} \mathrm{dL}^{-1}$ and urine creatinine is $88.5 \pm 11.1 \mathrm{mg} \mathrm{dL}^{-1}$ (de Castro et al., 2014). Serum and urine creatinine in this study reduced after administration 20 and $40 \%$ juice of leaves and stalks $M$. crenata.

Jagannath et al. (2012) reported that combination of $2 \% \mathrm{EC}$ and $0.75 \% \mathrm{AC}$ for 10 days induce raising urine calcium, oxalate and $\mathrm{CaC}_{2} \mathrm{O}_{4}$ crystals. These crystals caused ureter obstruction lead to urolithiasis. It triggers inflammation responses signed by high inflammatory cytokines, TNF- $\alpha$ and IL-1 $\beta$. Flavonoid as antiinflammation induced decreasing the production and releasing of TNF- $\alpha$ and IL- $1 \beta$ by immune cells. These responses are influenced by inhibition and inactivation effect of Protein Tyrosine Kinase (PTK) p56 (Yilmaz et al., 2011) and blocked transcription and translation process of cytokines (Abbas and Lichtman, 2012).

Urolithiasis patients cannot release urine normally. This condition generates the formation of Reactive Oxygen Species (ROS), causing tissue injury and failure of cells function. ROS activates nuclear factor kappa B (NF-kB) and IkB kinase (IKK) regulators. IKK as a complex enzyme induces cellular inflammation responses to form $\mathrm{IkB} \alpha$, which bind to $\mathrm{NF}-\mathrm{kB}$ as mediator of cells proliferation, inflammation responses and apoptosis factors (Dundar et al., 2001).

High-level ROS in the body tissues cause oxidative stress may induce escalation of lipid metabolic product and malonyldyaldehide (MDA). High level of MDA is one of predictor cellular tissues damage generated by free radicals (Kiefer, 2015). Increased free radical production in the kidney and elevated levels of urinary lipid peroxides are seen in experimental hyperoxaluric rats. Although the role of free radicals in the pathogenesis of kidney calcium oxalate $\left(\mathrm{CaC}_{2} \mathrm{O}_{4}\right)$ stones has not been established, have suggested that, at the start of the urolithiasis cascade, hyperoxaluria increases free radical production in the kidney and causes renal tubular cell damage (Huang et al., 2006).

Flavonoid in juice of leaves and stalks of $M$. crenata has antioxidant and anti-inflammation functions. As antioxidant, flavonoid directly donors its hydrogen ions to neutralized toxic effect of ROS. Flavonoid also acts as chelating agent of $\mathrm{O}$-groups in nitrite peroxide (ONOO-) (Hidayati et al., 2009). Moreover, flavonoid indirectly enhances endogenous antioxidant gene through some mechanisms, i.e., activation of nuclear related factor 2 (Nrf2) that induce synthesis of endogenous antioxidant enzyme gene of Superoxide Dismutase (SOD). SOD plays as free radicals scavenger (Nelson and Cox, 2008).

\section{Creatinine Clearance $\left(C_{c r}\right)$}

Creatinine clearance rate determines how efficiently the kidneys are clearing creatinine from the blood and serves as an estimate of kidney function. Therefore, creatinine levels in blood and urine may be used to calculate the creatinine clearance $\left(\mathrm{CrCl} / \mathrm{C}_{\mathrm{cr}}\right)$, which correlates with the Glomerular Filtration Rate (GFR). Blood creatinine levels may also be used alone to calculate the estimated GFR (eGFR) (Miller et al., 2010).

In clinical practice, however, creatinine clearance or estimates of creatinine clearance based on the serum creatinine level are used to measure GFR. Creatinine is produced naturally by the body (creatinineis a breakdown product of creatine phosphate, which is found in muscle). It is freely filtered by the glomerulus, but also actively secreted by the peritubular capillariesin very small amounts such that creatinine clearance overestimates actual GFR by $10-20 \%$. One method of determining GFR from creatinine is to collect urine (usually for $24 \mathrm{~h}$ ) to determine the amount of creatinine that was removed from the blood over a given time interval (Miller et al., 2010)

A low creatinine clearance value indicates low GFR and occurred in abnormal kidney function. The decline in kidney function can be either acute (sudden, often reversible) or chronic (long-term and irreversible). Repeated GFR or creatinine clearance measurements 
over time can identify kidney disease as acute or chronic (Kiefer, 2015). de Castro et al. (2014), reported that urine $24 \mathrm{~h}$. volume of Wistar rats are $10.9 \pm 2.2 \mathrm{~mL}$ and the $\mathrm{C}_{\mathrm{cr}}$ are $1.3 \pm 0.2 \mathrm{~mL} \mathrm{~min}^{-1}$.

Urolithiasis induced by combination $0.75 \%$ EG and $2 \%$ $\mathrm{AC}$ caused decreasing of $\mathrm{C}_{\mathrm{cr}}$, it is one signs for kidney tissue damage in urolithiasis condition. The function of kidney glomerulus decreased and loss it ability to filter and reabsorb substance selectively. $\mathrm{C}_{\mathrm{cr}}$ increased after administration juice of leaves and stalks of $M$. crenata.

Combination of $0.75 \% \mathrm{EG}$ and $2 \% \mathrm{AC}$ induce urolithiasis indicated by kidney and gallbladder tissues damage, including inflammation, haemorrhagic, lipid degeneration, necrosis and oedema (Murwani et al., 2015). Tissue damages may be caused by toxic effect of EG and AC, inflammation process, free radicals and tissue injury effect of urolithiasis. Treatment of rats with $M$. crenata 20 and $40 \%$ lower kidney tissue damages. These results revealed that antioxidant and anti-inflammation effect of juices leaves and stalks $M$. crenata prevent progression of tissue damage and improving kidney function.

\section{Conclusion}

From this research, it can be concluded that juice of leaves and stalks $M$. crenata have prevent disturbance of kidney function in urolithiasis $R$. novergicus animal model. Regeneration of injured tissue as well as improvement of kidney function could be achieved after administration of at least $20 \%$ juices leaves and stalks $M$. crenata.

\section{Acknowledgement}

The authors would like to thank Lelyta, Jefri, Bonanza, Mardiana, Dr. AchmadSabarudin, M.Sc., for the supports.

\section{Ethics}

This article contains material that is original and unpublished. The animal models had certificated by The Ethical Committee Medical Research of Medical Faculty, Brawijaya University (No. 421/EC/KEPK/07/2013).

\section{References}

Abbas, A.K. and A.H. Lichtman, 2012. Basic Immunology: Functions and Disorders of the Immune System. 4th Edn., Elsevier Health Sciences, Philadelphia, ISBN-10: 145575899X, pp: 336.

Afriastini, J.J., 2003. Cryptograms: Ferns and fern allies. LIPI. Bogor.
Anggraini, S., 2013. Uji aktivitas penghambatan pembentukan batu ginjal (anti nefrolitiasis) ektrak etanol dari herbal pegagan (centella asiantica (L) (urban) pada tikus putih Jantan. Sci. J. Bogor Agric. Univ., 2: 1-5.

Baker, H.J., R. Lindsey and S.H. Wesibroth, 1979. The Laboratory Rat, Volume I: Biology and Disease.1st Edn., Academic Pr, ISBN-10: 0120749017, pp: 435.

Buffington, C.A.T., 2001. Managing common chronic lower urinary tract disorders of cats. Proceedings of the North American Veterinary Conference, (AVC' 01), Orlando, pp: 282-285.

de Castro, B.B.A., F.A.B. Lolugnati, M.A. Cenedese, P.G.A. Suassuna and H.S. Pinheiro, 2014. Standardization of renal function evaluation in Wistar rats (Rattusnorvegicus) from the Federal University of Juiz de Fora's colony. J. Bras Nefrol., 36: 139-149. PMID: 25055353

Dundar, M., I. Kocak, C. Yenisey, M. Serter and B. Ozeren, 2001.Urinary and Serum Cytokine Levels in Patients Undergoing SWL. Brazilian J. Urol., 27: 495-499.

Ganong, W.F., 2003. Buku Ajar FisiologiKedokteran, Edisi ke-7. ECG. Jakarta.

Hidayati, A.M., Yusrin and A. Herlisa, 2009. Pengaruh frekuensi penggunaan teh daun tempuyung kering (sonchusarvensis) terhadap daya larut kalsium oksalat $\left(\mathrm{CaC}_{2} \mathrm{O}_{4}\right)$. Jurnal Kesehatan.

Huang, H.S., J. Chen, C.F. Chen and M.C. Ma, 2006. Vitamin $\mathrm{E}$ attenuates crystal formation in rat kidneys: Roles of renal tubular cell death and crystallization inhibitors. Kidney Int., 70: 699-710. PMID: 16807540

Jagannath, N., S.C. Somashekara, G. Damodaram and D. Golla, 2012. Study of antiurolithiatic activity of Asparagus racemosus on albino rats. Ind. J. Pharmacol., 44: 576-579. PMID: 23112416

Kang, H.W., S.P. Seo, W.T. Kim, Y.J. Kim and S.J. Yun et al., 2014. Effect of renal insufficiency on stone recurrence in patients with urolithiasis.J. Korean Med. Sci., 29: 1132-1137. DOI: $10.3346 / \mathrm{jkms} .2014 .29 .8 .1132$

Kiefer, D., 2015. Creatinine and creatinine clearance blood tests. WebMD, LLC.

Lerma, E.V., 2015. Blood urea nitrogen. Medscape.

Mariyani, 2009. Kasus urolithiasis pada anjingdan kucing. Institut Pertanian Bogor, Indonesia.

Miller, F.P., A.F. Vandome and M. John, 2010. Bladder Stone (Animal). 1st Edn., VDM Publishing, ISBN-10: 6132604545, pp: 80.

Murwani, S., P. Trisunuwati, L. Damayanti, J. Hardiyanto and B.W. Pradana et al., 2015. Preventive effect of Marsileacreanata leaves and stalks juice against urolithiasis in rats (Rattusnovergicus Wistran Strain). Procedia Chemistry Elsevier. 
Nelson, D.L. and M.M. Cox, 2008. Lehninger Principles of Biochemistry. 1st Edn., W.H. Freeman, New York, ISBN-10: 071677108X, pp: 1100.

NKF, 2015. Understanding your lab values. National Kidney Foundation Inc.

Purwono, R.M., 2009. Pengaruh Infusum Daun Alpukat (Perseaamericana Mill) dalam Menghambat Pembentukan Kristal pada Ginjal Tikus. Institut Pertanian Bogor.

Sparkes, A.H. and C.J. Philippe, 2008. Urolithiasis in cats-managing risks. Nestle Purina Pet Care.
Suharjo, J.B. and Cahyono, 2009. BatuGinjal.Kanisius. Yogyakarta.

Westropp, J.L., 2015. Urateurolithiasis in dogs and cats.G.V. Ling Urinary Stone Analysis Laboratory.

Yilmaz, H., Y. Giizel, Z. Onal, G. Altiparmak and S.O. Kocakaya, 2011. 4D-QSAR study of p56(lck) Protein tyrosine kinase inhibitory activity of flavonoid derivatives using MCET method. Korean Chem., 32: 4352-4360.

DOI: $10.5012 /$ bkcs.2011.32.12.4352 